\title{
LOVE OF FRANCE
}

\author{
Sylvia Townsend Warner
}

(from the New York Herald Tribune, August 1945)

During the fighting that freed Paris in August, 1944, a barricade in the Rue de Rivoli, constructcd, in the best architectural canon, of local materials, was topped off with a metal shop sign displaying the word Modes.

This, with its assertion that in Paris in August, 1944, a barricade was the correct wear for the Rue de Rivoli, was of course fortuitous ... but one of those fortuities that express a situation, as the colouring of a wild flower will express a geological condition.

Respect for local materials is one of the elements in French culture. It underlies their art as it does their cookery. Whether they build a chateau or a barricade they will employ the means of the neighbourhood with appreciation

Plus me plaist le sejour qu'ont basty mes ayeux

Que des palais Romains le frout audacieux,

Plus que le marbre dur me plaist l'ardoise fine.

To be homesick is common to all mankind; but du Bellay's sonnet (it seems to me) is characteristically of France in its exact statement of what home is made of. I cannot imagine an Elizabethan poet, however much he longed to return to his small manor, particularising that it was roofed with thin slates: his love of home would have persuaded him that it was roofed with something quite as grand as any Roman marble. Because of this digested regionalism, French culture has been little troubled by the folk-art movements which other nations 
have had to undergo as a penance for not appreciating their natural resources. There is as much folk song, folk design, folk lore in France as anywhere else; but it has passed naturally into the idiom of the country, it does not appear with that anxious resurrected stare of what has been revived.

But how does it come about, this peculiar compactness and homogeneity of French life and culture? Certainly not from seclusion. France has always been receptive to ideas from elsewhere, it has exemplified the including aspect of Roman Imperialism as this country has exemplified Roman Imperialism's other aspect of extension. Our colonies are abroad; but the French colonial empire includes colonies within her borders, settlements from all over the world, the kind of colony inaugurated with the Latin Quarter, a district where scholarship, love of learning, love of thinking, drawn from all Europe met and settled around the University of Paris.

No seclusion: and not - in our sense of the word patriotism. 'I love my country as I might love a beautiful woman. I love her and I see her faults.' So, long ago, I heard a French student trying to explain to English hearers how he felt about France. The words were rivetted into my memory by the clamour of reprobation which broke out after he had gone. Who'd admit, and among foreigners, that one's country might have faults? Shocking, unnatural, cried those English voices.

But in the sense of loving one's country as a beautiful mistress rather than loving her as an irreproachable grandmother, the patriotism of France may explain the homogeneity of France. It is the glory of France that her nationals have watched her with the critical and jealous glances of a lover, exclaiming: 'I'm not sure of that shade of blue. I prefer you with pearls. Take care. There's a midge going to bite you. You have a smut on your nose. You must leave that tailor, he's not worthy of you.'

For it is impossible to be in France without becoming aware of this critical solicitude, whether it is the man tying up lettuces in his allotment, the girl leading the cow along to stake her in a fresh bit of pasture, the artist and the housepainter alike standing back to consider their brush-work, the 
woman in the kitchen who tastes and muses, the man in the café who is talking politics, who leans forward, his cheek on his hand and says, Pourtant. ... And it is out of this habit of criticism and solicitude that France has become, not merely a territory, a nation, a manner of living, a collection of habits and turns of thought, but something approximating to a work of art.

Art is never a gentle process. From the violent stillness of conception to the violent restraint of execution, art is something in which mind and body are exerted to the limits of capacity. Above all, art demands the most violent candour. If France has this quality of approximating to a work of art, it is because her nationals have not failed in violence. Mother of arts, and arms, and laws, she is also the daughter of revolutions. The Rue de Rivoli, amiably purveying its pretty nonsenses for foreign buyers, can also supply its barricades. A barricade is also Modes, and fighting for liberty a characteristic elegance of France.

I say elegance, because I mean elegance. Whoever saw the film of the Liberation of Paris must have been struck by the predominant expression on those thin and fighting faces, by the peculiar air of lucidity in all those rapid movements. Through all the violence, the desperation, the danger, there was the dexterity and composure of people who, as in the execution of a work of art, are exerting mind and body to the limit of capacity, to the limits of life itself, and who know what they are doing and why. It was almost like watching sword-play or watching the flight of swallows. Yet it was not because the combatants were young, though many of them were young; nor because they were physically skilful, for some of them were old and clumsy. It was because they were mentally skilful, technicians of liberty. What one watched was an exhibition of civilised behaviour in that pre-eminently civilised act of rooting out fascism. It was another masterpiece of France, prepared with critical solicitude, with the discipline of patience, endurance, cunning, audacity, and martyrdom, and executed in local materials, the men and women of the French Resistance. 